\title{
Dispatch
}

\section{Reflections on Conversations and Dialogues with Recent Settlers}

\author{
ADRIAN M. DOWNEY \\ Mount Saint Vincent University, Canada
}

If you have come here to help me, you are wasting your time. But if you have come because your liberation is bound up with mine, then let us work together.

Attributed to Lila Watson, Gangulu Elder, but generated through the collective resistance of Australian Indigenes (quoted in Patel, 2012)

In the summer of 2012, I worked at an international summer language camp. It was my first professional teaching experience, and when I introduced myself to the roughly 150 students, I did so as I normally do: "My name is Adrian; I am Mi'kmaq." I didn't expect many students to know what being Mi'kmaq meant, but I considered it important to share that piece of myself.

One day, I started chatting with a few students from Germany. One told me that she had learned about the Mi'kmaq in her history class, and that she had done her final project for that year on what she called "American Indians." I asked her what she had learned about my people, and she proceeded to paint a vivid picture of Mi'kmaw life before and after contact. It has been too long for me to remember the exact image held in her words, but suffice it to say that I was not the Indian she had in mind. The Mi'kmaq were history for her - they certainly weren't English teachers working at prestigious international private schools like I was. As the conversation went on, I became more and more uncomfortable with the image this student held of the Mi'kmaq and, by extension, me. I soon realized that she was tacitly comparing me to the Mi'kmaw people about whom she had learned. Everything I did inevitably became part of her existing understanding of what the Mi'kmaq were. I don't remember how our conversation ended, but I do remember the lingering feeling of being observed.

After this incident, I began to wrestle with how I both reify and complicate the messages presented in other countries about North American Indigenous 
people through my presence as a teacher of international students. Questions ran through my head: Does the fact that I didn't grow up on a reservation take away from my perceived authenticity? Do I complicate damage-centered narratives through my privilege? When I speak the words I know in Mi'kmaw language or talk about Mi'kmaw culture, how do students see me? How do their perceptions of Mi'kmaw people change or stay the same based on our interactions? When I am not recognized as Mi'kmaw because of my white skin, do I tacitly continue the erasure of Indigenous peoples upon which settler colonialism is built? Many of those questions still linger today.

This was one of my first conversations with a recent settler, ${ }^{1}$ but it certainly hasn't been my last. In the last decade, there have been two constants in my life: conversations with recent settlers and a journey to understand what it means for me to be Mi'kmaq in the modern world. In this dispatch, I reflect on the intersection of those two constants. In particular, I draw on two significant relationships in my life with recent settlers in order to discuss coresistance, solidarity between marginalized peoples, and the common quest for self-understanding I consider to be at the core of reconciliation and social justice. More specifically, the purpose of this piece is to showcase the potential of solidarity not just to produce material, on the ground changes through networks of resistance, but also to open us up to new possibilities and understandings of ourselves and others through relationships. Before addressing solidarity and self-understanding explicitly, however, I will provide some insight into the geopolitical context in which I am writing - the Canadian nation-state in the age of reconciliation.

\section{Reconciliation in Canada}

In 2015, the Truth and Reconciliation Commission (TRC) of Canada released its final report (TRC, 2015). The TRC was a nation-wide inquiry into the abuses and traumas suffered by Indigenous people through the federally run residential school system. For over 100 years between the $19^{\text {th }}$ and $20^{\text {th }}$ centuries, Indigenous children were forcibly taken from their families and made to attend poorly funded, church-run "schools," which operated under the explicit mandate of "killing the Indian in the child" (Young, 2015, p. 63). Apart from the cultural genocide associated with being punished for speaking Indigenous languages or practicing culture, physical, sexual, and emotional

\footnotetext{
1 "Recent settler" is a term sometimes used to refer to people new to a traditional Indigenous territory; not everyone is comfortable with this terminology, but some prefer it to the term "immigrant," which has taken on pejorative connotations. Here, I use recent settler to refer to people born in countries other than Canada who now live in Wabanaki territory. I use this term to emphasise the way global mobility and globalization perpetuate forms of settler colonialism that, despite individual reasons for resettlement, have a continued negative impact on the right and ability of Indigenous peoples to manage and benefit from the land. I remain respectfully open to discussion and suggestions on the use of this term.
} 
abuse were commonplace in these institutions. The TRC has started the process of raising awareness about this often purposefully overlooked portion of Canadian history. Indeed, in the four years since the TRC report was released, institutions, governments, and the public have become increasingly aware of the Indigenous nations in Canada and the ways in which Indigenous people have been and continue to be marginalized, disenfranchised, and dispossessed of land.

Over the last few years, I have noticed an increased fluency with the discourse of reconciliation - a discourse Dene scholar Glen Coulthard (2014) might call a marker of the politics of recognition. It has become a discourse of righting past wrongs concerned with much more than just residential schools, but the entire history of colonization, genocide, abduction, and paternalism that Indigenous people in Canada have endured. Within this discourse, many settlers choose to focus on the pathways forward. Educators and researchers speak about the need to form a bridge between two worldviews, the Indigenous and the Western. Administrators speak of Indigenizing the academy, welcoming Indigenous knowledges into the dominant model of academia. Politicians say that we are all treaty people - a statement of their belief that they have an obligation to renew the relationships codified in the treaties between the British Crown and the sovereign Indigenous nations of the territory now labeled Canada. In my home territory of the Wabanaki Confederacy, ${ }^{2}$ or what is today thought of as Atlantic Canada, those treaties were named the Peace and Friendship Treaties. Through the Peace and Friendship Treaties, the Wabanaki peoples never surrendered, ceded, or sold land. Instead, those treaties guaranteed Indigenous rights to land - all land not occupied by settlers at the time the treaties were signed around 1763 (Paul, 2006). Needless to say, much territory has been lost since then, but it was never given up by legal means; it was stolen (see Bear Nicholas, 2011). Some Indigenous people see the path forward as one of honouring those treaties in the spirit of reconciliation, where reconciliation is about building sustainable relationships between Indigenous and non-Indigenous people (TRC, 2015). Some Indigenous people also look at the reconciliation movement as an opportunity for resurgence - a chance for Indigenous people to assert their sovereignty over their territory and reclaim the spaces that have been taken from them through settler colonial patterns of dispossession (Simpson, 2017). These resurgent efforts occasionally result in conflict. In recent memory, one thinks of the anti-pipeline land defenders in British Colombia and the anti-fracking movement in New Brunswick. For Indigenous people, it is a sacred obligation to defend the land, and there is a long history of fighting the government over land (e.g., Hill, 2009). It has only been recently, however, with the interrelated reconciliation, resurgence, and \#idlenomore movements

\footnotetext{
${ }^{2}$ The Wabanaki Confederacy is a union between five groups of Indigenous people on the East Coast of Canada and The United States.
} 
reaching public consciousness, that it seems as though some settlers understand why Indigenous people are demonstrating - not to be needlessly dissident, but because land was taken, land with which intimate relationships still exist.

In his 2003 Massey Lectures, Thomas King alluded to the notion that repeating the history of colonization, residential schools, and Indigenous dispossession is a way of saying "once upon a time" for Indigenous storytellers. It is a history shared among the Indigenous peoples of Turtle Island, a common experience with unique manifestations in every territory and every lived reality. It is a complex, nuanced, traumatic, and difficult story that for many generations, primarily Indigenous people understood and spoke about. But today, many non-Indigenous people are starting to understand elements of that story and, more importantly, that the traumatic history of settler colonialism isn't the whole story, just the introduction.

The ongoing history of settler colonialism in Canada is complex and multifaceted, and when someone comes to this territory from another part of the world, they are dropped into that ongoing history with little, if any, contextualization - and more often than not stereotypical misunderstandings fueled by colonial education systems and ubiquitous media misrepresentations. Often, they come from a place with its own history of colonization and, as they (re)build their lives in Canada, they begin to experience forms of marginalization to which they may not be accustomed. It is, thus, completely understandable that many recent settlers in Canada have little relationship with or knowledge of Indigenous people (Chung, 2012; Sivaneswaralingam et al., 2017; see also Clark \& de Costa, 2011). This is, of course, not universally the case as evidenced by intercultural dialogue programs in Winnipeg (Gyepi-Garbrah et al., 2014) and Vancouver (Zand, 2018), but the norm continues to be isolation between Indigenous and recent settler communities, particularly in less densely populated urban settings such as those in Atlantic Canada. In this essay, I add my voice to the long line of those concerned with disrupting the norm of isolation between Indigenous and recent settler communities (e.g., Kuropatwa, 2015; Sivaneswaralingam et al., 2017; see also Lawrence \& Dua, 2005). Here I share my experiences of building relationships across culture and gesture toward the potential in diasporic and Indigenous communities of coming together in resistance.

\section{Conversations and Co-Resistance}

Gonen Sagy is originally from Israel. He completed his $\mathrm{PhD}$ there in multicultural aspects of environmental education and went on to run a peace education program which brought together Palestinian and Israeli students in conversations and activities around sustainability and their shared environment. When I first met Gonen, he had just come to Canada and was my instructor in a course on critical thinking. In that context, we had many 
conversations about education, philosophy, life, and peace. One persistent topic in our conversations was the movement toward reconciliation. After the course ended, Gonen and I co-authored a conversational chapter on education and social justice (Downey \& Sagy, 2018). In the process of writing that chapter, we continued to connect over reconciliation. Perhaps because of his experience in peace education or his previous existence as occupier within occupied Palestine, Gonen was eager to understand the reconciliation movement, the history of this territory, and to build relationships with Indigenous people. Today, Gonen teaches Hebrew to middle school and high school students. He lives in Ottawa, but we continue to speak on the phone a few times a month.

My relationship with Gonen has taught me the spirit of co-resistance and the power of networks of resistance. I borrow the term co-resistance from Leanne Betasamosake Simpson (2017), for whom the concept is a way of decentering whiteness in solidarity and building meaningful relationships between marginalized people, particularly Black Canadians, people of colour, and Indigenous people. Co-resistance as a term subverts the competitive language of diasporic space and Indigenous place (Coleman, 2016), inviting diasporic and Indigenous communities to share physical $\mathrm{sp}(1)$ ace toward the disruption of the systemic structures which facilitate mutual oppression. The spirit of co-resistance, for me, is elucidated in the Lila Watson quote referenced at the beginning of this piece (see Patel, 2012). The various marginalizations endemic to the fabric of modern society (racism, ableism, gender discrimination, settler colonialism, etc.) are intertwined in complex socio-economic, historical, and political webs. Within those webs, hierarchies are created (Mitchell, 2018). Through the comparative, competitive ideologies of militarised capitalism, we are conditioned to find inadequacies in others in order to raise ourselves up. Lived co-resistance, perhaps in the spirit of intersectional feminism, asks us to put aside those imposed hierarchies in order to work together as a community toward our mutual liberation and toward the overthrow of hegemonic settler-colonial patriarchy.

Theoretical description aside, when I think of co-resistance I think of networks. In the small city in which I live, Fredericton, New Brunswick, groups of committed activists organize and take part in a variety of activities - lectures, prayer vigils, protests, marches, and publications (e.g., NB Media Co-op). Since moving to Fredericton three years ago, I have been invited to these events through e-mail, social media, word of mouth, text-message, and (my personal favorite) colourful notes stuck to my office door. This, to me, is being a part of a network built on co-resistance. Simpson (2017) articulates the organization of co-resistance using the idea of constellations or "small collectives of people coming together to organize a particular event, or to create or hold Indigenous presence that in some way [is] disruptive to settler colonialism" (p. 216). Further, constellations of people can come together, disband, and re-form as needed (Simpson, 2017 p. 217). My experience with networks supports this: I might not see the people in these networks every 
day or at every event, but we know how to reach each other when something important is happening.

The people who form the activist networks in Fredericton come from all walks of life, diverse countries of origin, and a variety of identity positions. At first, I thought the success of these networks was because the size of Fredericton (pop. 58,000) doesn't allow us the luxury of working in isolation. In 2018, however, Gonen invited me to the Empowering Sustainability Gathering at University of California Irvine. There, I met with sustainability activists from all over the world and became a part of a global network of committed environmentalists. Gonen was one of the first members of the group and has attended the gathering almost every year since its inception. Over the years, the group has collaborated on a number of projects in areas such as healthcare, alternative economic technologies (i.e., cryptocurrency), and education, but most importantly every year they come together to share stories, receive critical feedback from one another on their current projects, and build and sustain personal relationships. The people in the Empowering Sustainability community are what make it a resistant space, and it is personal relationships that are at the center of co-resistance. When we are connected to each other personally, we can help each other and hold each other to account regardless of the cultural or physical space between us.

When we are personally connected to each other, we also have the opportunity to understand each other. The aim of Gonen's work in peace education was bringing together people from groups in conflict. As they sat in each other's presence and spoke to one another directly, they were able to see that the myths and stereotypes they held about each other as individuals within conflicted collectives were not true. They were able to build personal relationships, and those relationships became a new, perhaps counter-cultural, reality. Social justice is rightfully concerned with shifting material reality the physical circumstance of oppression. For me, the first step in making structural change is establishing and deepening real, human relationships. In Simpson's (2017) discussion of networks, she is skeptical of the internet and social media because of the ways in which they are interwoven with settler colonial, capitalist power structures. For Simpson, constellations of coresistance need to be built on real, in-the-world relations. In my experience, activist networks can bring us into contact with people with whom we might not normally engage. That opportunity is a gift and a privilege. In those relationships, we are called on to grow and encompass what we learn from others. That growth can be painful at times, but it is always worth it. My relationship with another recent settler, Ashwani Kumar, further demonstrates the potential for this kind of growth in relationships between Indigenous folk and recent settlers. 


\section{Dialogue and Self-Understanding}

When I came across Ashwani's work (Kumar, 2011, 2013), ${ }^{3}$ I was totally enthralled by the way it brought together the intellectual rigour of critical theory and the evocative nature of spiritual philosophy. When we sat down to speak with one another later that year, it was clear that we shared a common desire to explore the internal and external complexities of oppression. Since that initial meeting, Ashwani and I have engaged in a number of serious dialogues, many of which were a part of a dialogic research project focused on Ashwani's concept of meditative inquiry in a variety of contexts including education and music. I served as a graduate research assistant and collaborator for the project, and several of these dialogues have now been published (Kumar \& Downey, 2018, 2019).

Ashwani and I are both concerned with social justice in education. As educators, we often see injustice in a myriad of forms revealed within our classrooms and in the lives of the students we teach. When I encountered Ashwani's work, I began to open up to the idea that social justice in education starts with individual change. This sentiment was later echoed for me through the Wolastoqiyik word piluwitahasuwawsuwakon, ${ }^{4}$ which is often used to talk about reconciliation and directly translates as "allowing your thinking to change so that action will follow in a good way toward truth" (Pye, 2019). The teaching of piluwitahasuwawsuwakon acknowledges the role of internal work in the movement toward social change. While this internal emphasis doesn't replace the structural changes we need to see, it does provide a tangible starting place - through self-understanding.

For Ashwani, deep understanding of who we are is a counter-cultural act and a necessary first step in moving toward social justice. In other words, before we can move toward decolonization and reconciliation as a society, we must start within ourselves. Ashwani's work helps in that process by analyzing the competitiveness of dominant ideologies (i.e., the hierarchies of patriarchal capitalism). Hierarchical and competitive thinking facilitates the construction of societal ideals, and those ideals distance us from understanding ourselves. The problem with these ideals is that they are not obtainable, and when we inevitably fall short of them we see our actual selves as inadequate, thus resulting in complex internal conflicts. Take fear as an example. I am taught that to be a "good man," I must be brave (ideal); however, I often find myself in situations that make me fearful (my actual self). In order to attempt to fulfill the ideal, I hide my fear from others and from myself (internal conflict). Ashwani asks us to accept what is rather than trying to become other than what we are in the pursuit of external ideals. This

\footnotetext{
${ }^{3}$ A full treatment of Ashwani Kumar's work is beyond the scope of this essay. For further reference, see Kumar $(2013,2019)$ and Kumar and Downey $(2018,2019)$.

${ }^{4}$ Piluwitahasuwawsuwakon was brought forward to the University of New Brunswick as an alternative to the term reconciliation by Elder Opolahsomuwehs (Imelda Perley) (D. Perley, personal communication, April 15, 2019).
} 
self-acceptance alleviates the tensions of striving to become, thereby cultivating an internal landscape at peace with itself. From that position we can begin to understand who we are, where we come from, why we are here, and where we are going. ${ }^{5}$

In more practical terminology, sitting with Ashwani in mutual, authentic dialogue helped me understand myself apart from what society tells me I should be - like getting an outside perspective on my own colonization. Here, I think back to my conversation with the German student. Whether she knew it or not, she had an idea of who I should be according to her perception of my Mi'kmaw label - an image she had formed through her studies on "American Indians." Her communication of that image to me in turn triggered my thinking on what it meant to be Mi'kmaq and how I compared to my own ideal. The lingering discomfort I felt was both that of being compared to her abstract and that of comparing myself to my ideal. In dialogue, the ideals and expectations we have about others break down just as readily as do the myths and stereotypes. The complexity of another human life is undeniable and calls on us to rethink the simplistic narratives woven for us about other people and about ourselves. That rethinking, for me, is the starting point of social justice.

My activism mostly happens in the classroom. While I am also involved in other forms of resistance, including critiques of the very education system in which I work, the bulk of my time is spent engaging the critical spirits of students and building allies, alliances, and solidarity. In this work, my own self-understanding and personal decolonization provides me a strong base from which to move forward. Because I understand more fully who I am and where I come from, I can often help students understand their own biases. In moments similar to the ones described above, I am able to work with students in deconstructing the images they hold of others. In education, these small, personal changes can make tangible, structural impacts. The students with whom I work go on to become teachers, principals, education directors, and curriculum consultants - people who make decisions that affect the lives of thousands of marginalized students. I don't just want those people to be Indigenous allies; I want them to understand the interconnected and intersectional nature of marginalization. I want them to see the ways they are implicated in that marginalization and the ways they carry their biases around with them. For me, those changes have to start on the inside.

The point of this section has been to articulate the internal, psychological, and spiritual benefits of solidarity and co-resistance between Indigenous people and recent settlers. Simply put, the process of dialogue brings us closer to understanding who we are and why we are here. From that position of understanding, we are better equipped to deal with the competitive and

\footnotetext{
5 "There are four questions every Indigenous person must answer in order to understand who they are" (Talaga, 2018, pp. 17-18). The versions of the questions posed above are often asked by Mi'kmaw Elder Albert Marshall to help us understand our role in reconciliation and life more broadly.
} 
comparative ideologies of capitalism thrust upon us and those with whom we engage in the classroom and beyond.

\section{Finding Self, Finding Voice}

The purpose of this piece is to showcase the potential of solidarity between Indigenous peoples and recent settlers in two interconnected and interwoven areas: (a) collaborative activism through networks of co-resistance, and (b) mutual and self-understanding through intercultural dialogue and building of sustainable relationships. I have felt the deep connections between these two areas continually throughout my life. A quick conversation with a student from Germany left me struggling with who I am and what my identity represents. A longer and ongoing conversation with a colleague and friend created avenues for co-resistance and solidarity and allowed me to develop an appreciation for the value of activist networks. Finally, deep dialogues with a mentor and friend helped me understand who I am and the ways in which I, and the colonial society in which I live, have distanced myself from myself. Through all of these relationships, I learned a great deal about the world and about my place in it. I also hope that I brought something unique to these relationships and, indeed, to the many other conversations I have had with recent settlers as a teacher, an activist, and a human being. I hope that I was able to welcome my friends, colleagues, and students to Wabanaki territory, as has been the tradition of the Mi'kmaw people for generations. I hope that I was able to demonstrate and exemplify balanced ways of living with the land, a right for which many Indigenous people have fought. Most of all, I hope that I was able to heal some misconceptions about Indigenous people, many of which are as thoroughly engrained in our own internal landscapes as those of settler society. I may never know the effect of my words or of my relationships, but I hold to the hope that in solidarity and co-resistance we can help each other find our voices and speak back to diverse forms of power, both externally and internally.

\section{References}

Bear Nicholas, A. (2011). Settler imperialism and the dispossession of the Maliseet, 1758-1765. In J. G. Reid \& D. J. Savoie (Eds.), Shaping an agenda for Atlantic Canada (pp. 21-60). Fernwood Publishing.

Chung, M. (2012). The relationships between racialized immigrants and Indigenous peoples in Canada: A literature review [Master's thesis, Ryerson University]. Ryerson University Library Digital Repository.

Clark, T., \& de Costa, R. (2011). Exploring non-Aboriginal attitudes towards reconciliation in Canada: The beginnings of targeted focus group research. In A. Mathur, J. Dewar, \& M. DeGané (Eds.), Cultivating Canada: Reconciliation through the lens of cultural diversity (pp. 327-339). Aboriginal Healing Foundation. 
Coleman, D. (2016). Indigenous place and diaspora space: of literalism and abstraction. Settler Colonial Studies, 6(1), 61-76.

Coulthard, G. S. (2014). Red skin, white masks: Rejecting the colonial politics of recognition. University of Minnesota Press.

Downey, A., \& Sagy, G. (2018). Young Eagle and Hoopoe: Conversations from the forest. In M. J. Harkins, \& S. Singer (eds.), Educators on schooling, social justice and diversity: A reader (pp. 256-267). Canadian Scholars' Press.

Gyepi-Garbrah, J., Walker, R., \& Garcea, J. (2014). Indigeneity, immigrant newcomers and interculturalism in Winnipeg, Canada. Urban Studies, 51(9), 1795-1811.

Hill, G. (2009). 500 years of indigenous resistance. PM Press.

King, T. (2003). The truth about stories: A native narrative. House of Anansi Press.

Kumar, A. (2011). Understanding curriculum as meditative inquiry: A study of the ideas of Jiddu Krishnamurti and James MacDonald [Doctoral dissertation, University of British Columbia]. UBC Theses and Dissertations.

Kumar, A. (2013). Curriculum as meditative inquiry. Palgrave MacMillan.

Kumar, A. (2019). Curriculum in international contexts: Understanding colonial, ideological and neoliberal influences. Palgrave Macmillan.

Kumar, A., \& Downey, A. (2018). Teaching as meditative inquiry: A dialogic exploration. Journal of the Canadian Association of Curriculum Studies, 16(2), 52-75.

Kumar, A., \& Downey, A. (2019). Music as meditative inquiry: A dialogical exploration of learning Indian classical music. Artizein, 4(1), 98-121.

Kuropatwa, R. (2015, December 16). The connection between immigrants and Aboriginal people in Canada's mosaic. Canadian Immigrant. http://canadianimmigrant.ca/community/theconnection-between-immigrants-and-aboriginal-people-in-canadas-mosaic

Lawrence, B., \& Dua, E. (2005). Decolonizing antiracism. Social Justice, 32(4), 120-143.

Mitchell, S. (2018). Sacred instructions: Indigenous wisdom for living spirit-based change. North Atlantic Books.

Patel, S. (2012, August 1). Defining Muslim feminist politics through Indigenous solidarity activism. The Feminist Wire. https://thefeministwire.com/2012/08/defining-muslimfeminist-politics-through-indigenous-solidarity-activism/\#_edn 12

Paul, D. (2006). We were not the savages: Collision between European and Native American civilizations (3rd ed.). Fernwood Publishing.

Pye, K. (2019, February 22). Forging a new path: Amanda Reid Rogers installed as UNB's first Piluwitahasuwin. UNB Newsroom. https://blogs.unb.ca/newsroom/2019/02/forging-a-newpath-amanda-reid-rogers-installed-as-unbs-first-piluwitahasuwin.php

Simpson, L. (2017). As we have always done: Indigenous freedom through radical resistance. University of Minnesota Press.

Sivaneswaralingam, M., Bhatty, H. S., \& Lam, A. (2017). Factors that affect Scarborough immigrant women's knowledge of indigenous contexts [Unpublished manuscript]. Department of Sociology, University of Toronto Scarborough. https://www.utsc.utoronto.ca/immigrantscarborough/sites/utsc.utoronto.ca.immigrantscarbo rough/files/docs/SOCD15\%20Final\%20Report\%20Meena\%2C\%20Sonia\%2C\%20Anita_0 .docx

Talaga, T. (2018). All our relations: Finding the path forward. House of Anansi Press.

Truth and Reconciliation Commission of Canada. (2015). Final report of the Truth and Reconciliation Commission of Canada, volume one: Summary. Honouring the truth, reconciling for the future. James Lorimer \& Company.

Young, B. (2015). "Killing the Indian in the child": Death, cruelty, and subject-formation in the Canadian Indian residential school system. Mosaic: A Journal for the Interdisciplinary Study of Literature, 48(4), 63-76.

Zand, A. (2018). Decolonizing capacity building and leadership development for Indigenous and newcomer youth through intercultural dialogue: A case study of Surrey, British Columbia [Master's capstone report]. School of Community and Regional Planning, University of British Columbia.

https://scarp.ubc.ca/sites/scarp.ubc.ca/files/Zand\%20\%28Amitai\%29\%20Capstone $\% 20$ Rep ort.pdf 